v. $12, n .3$

\title{
Value Premium and Country Risk as Dimensions to Estimate Conditional Returns: a Study of the Brazilian Market
}

\author{
Lilian de Castro Medeiros ${ }^{\dagger}$ \\ Central Bank of Brazil \\ Aureliano Angel Bressan ${ }^{\Omega}$ \\ Minas Gerais Federal University
}

\begin{abstract}
Asset pricing is a widely explored theme in the financial literature. Nevertheless, the phenomenon of value premium is still controversial, since although easily detected in developed and emerging markets, little is know about the economic forces that explain its existence. In this context, this article examines value premium in the Brazilian market and investigates the influence of the country risk variable as an additional risk factor for estimating conditional returns in this market not captured by value premium. For that, we employ a five-factor model, formulated by adding the country risk factor to the model of Carhart (1997). We apply the statistical procedure adopted by Fama \& French (1993) to the period between 1994 and 2012, with data on nonfinancial companies listed on the BM\&FBovespa. The results confirm the existence of value premium in the Brazilian market, and country risk and value premium together are significant factors to explain conditional returns.
\end{abstract}

Keywords: Value premium. Country risk. Conditional returns.

Received on 11/04/2013; accepted on 12/12/2013; disclosed on 05/04/2015.

*Author for correspondence:

. M.Sc. from Minas Gerais Federal University

${ }^{\Omega} \mathrm{Ph} . \mathrm{D}$. from Viçosa Federal University Institution: Employee of the Central Bank of Brazil Address: Rua Groenlândia, 401/1004, Bloco 1, Institution: Associate Professor at Minas Gerais Federal University Sion, Belo Horizonte - MG - Brazil Address: Rua Manhumirim, Belo Horizonte - MG - Brazil

E-mail: lilian.c.medeiros@gmail.com E-mail: aureliano.bressan@gmail.com Telephone: (31) 9208-7806

Telephone: (31) 9683-4433

Note from the Editor: This article was accepted by Emerson Mainardes. 


\section{INTRODUCTION}

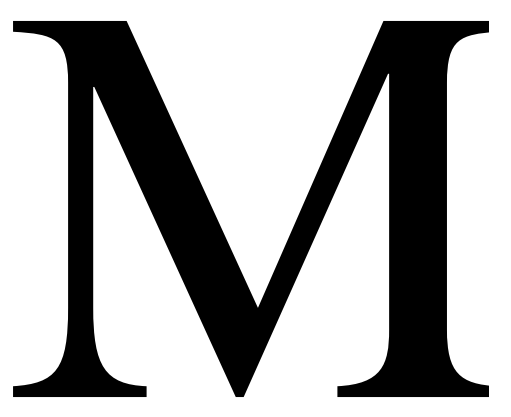

arkets are considered efficient when stock prices immediately reflect all the information available about firms. If these prices follow a certain pattern, it is said that the market has anomalies that enable investors to obtain abnormal gains (FAMA, 1970). Studies of many countries, including Brazil, such as those by Fama \& French (1992, 1993), Lakonishok, Shleifer \& Vishny (1994), Mescolin, Braga \& Costa Jr. (1997), Phalippou (2004, 2008), Málaga \& Securato (2004), Zhang (2005), Kouwenberg \& Salomons (2005), Mussa et al. (2007) and Machado \& Medeiros (2011), indicate the presence of a persistent anomaly: value premium, defined as the risk premium paid for stocks of firms characterized as having low market value when analyzed according to their expected cash flows, dividend payouts, historical prices, equity value or any other measure of firm value (stocks defined in the literature as value stocks).

For many years the above-mentioned researchers have observed that the average return generated by value stocks tends to be greater than that generated by stocks characterized as having a high market price compared to measures of firm value (called growth stocks), a similar result to that obtained by Chen \& Lakonishok (2004) and Wang \& Yu (2011). Fama \& French (2006) also found evidence that the size of value stock companies tends to be smaller, confirming the results found in their initial studies carried out in 1992.

However, there is a good deal of evidence that contradicts the findings of the above authors. For example, there are countries where growth stocks generate a higher average return for investors, countries in which larger companies are also more profitable and countries where it is impossible to establish any relation between value premium and the risk assumed by investors (PUTRANTO, 2009, p. 9). Furthermore, Kouwenberg \& Salomons (2003) found evidence that countries with high and low book-to-market value ratios differ significantly in terms of their local macroeconomic conditions, and that the exposure of portfolios to these macroeconomic factors is responsible for $40 \%$ of the value premium.

In this context, it is worthwhile to study the relationship between the macroeconomic variable country risk, which can be considered the average risk of public and private bonds in a determined country, and the value premium, to ascertain whether the former variable can be considered a new dimension of risk for estimating conditional returns not captured by the value premium. 
Since the country risk is related to the costs of raising new debt capital, via sovereign or private issues, it is important to investigate the correlation and possible causality between, on the one hand, qualitative country risk classifications, and on the other the risk premiums charged in the secondary bond markets. Therefore, we decided to examine the possibility of country risk being considered a new risk dimension for conditional returns in the Brazilian market, captured by the EMBI Global, as well as to check whether that risk is no longer captured by the value premium measure.

Our general objective, then, consists of verifying the possibility of adding country risk to the asset pricing model as a variable to predict stock returns. For that purpose, we tested the following hypotheses:

Hypothesis 1: Value premium exists in the Brazilian market.

Hypothesis 2: The value premium of Brazilian stocks behaves in the same way as it does in the American stock market.

Hypothesis 3: Country risk should be added to the asset pricing model as a variable to predict stock returns, since it is a dimension of conditional returns not captured by the value premium.

This article is divided into four parts. The first is a brief review of the related literature. The second presents the data and method, detailing the procedures for building the portfolios and comparing the models. The third part contains the analysis of the results obtained in light of the relevant literature. Finally, the conclusion analyzes the main contributions of this study and suggests some avenues for future research.

\subsection{SOVEREIGN RISK AND COUNTRY RISK}

Sovereign risk is the credit risk associated with transactions with sovereign states, i.e., that related to the risk of default by the government on sovereign bonds (MOODY'S, 2001). Hence it only refers to the capacity and willingness of the central government to honor its debts to private creditors, not including bilateral credits and lending of multilateral institutions (such as the World Bank and IMF) or, directly, the probability of default of subnational governments, state-controlled companies or private companies.

Country risk, although strongly related to sovereign risk, is a broader concept that also involves the risk of default of the other debtors in a country. Therefore, it is a risk premium metric paid by all financial assets of the country: 
[...] Country risk is therefore a broader concept than sovereign risk is, which is restricted to the risk of lending to the government of a sovereign nation. An assessment of the willingness to pay, for example, is one of the distinguishing features of sovereign credit analysis compared to corporate credit analysis. Country risk assessment does not only involve an assessment of willingness of the state to fulfil its obligations, as other factors can also cause losses. In practice, sovereign risk and country risk are highly correlated, however, as the government is the major actor in sovereign and country risk affairs (CLAESSENS; EMBRECHTS, 2003, p. 3).

According to data from Moody's (1997), the yield differential of risky assets is determined by the degree of risk aversion of investors, by the particular risk that investors attribute to each asset and by the general conditions of liquidity of each asset. In this sense, the country risk ratings applied to a country's bonds are important because they directly affect the prices: since they are used as a reference to approximate the credit risk, they reduce the information asymmetry of the market and compose the prices of available assets, attenuating investors' risk aversion.

The market indexes most commonly used with regard to the risk premiums paid by securities in emerging economies are the $\mathrm{EMBI}^{+}$(Emerging Markets Bond Index Plus) and the EMBI Global (Emerging Markets Bond Index Global), both created by JPMorgan "in response to investor demand for a benchmark that includes the most strategic investment opportunities readily available in the emerging markets" (MORGAN, 1995, p. 1). In addition to being used as a benchmark, these indices "provide investors with a definition of the market for emerging markets external-currency debt, a list of the traded instruments, and a compilation of their terms" (MORGAN, 1995, p. 1).

According to JP Morgan, these indexes are composed of a basket of bonds issued by central governments of various emerging countries, traded in secondary markets, involving external and domestic debt. Both only consider "issues denominated in U.S. dollars, with a minimum current face outstanding of US\$ 500 million and at least $2 \frac{1}{2}$ years to maturity" (MORGAN, 1999, p. 2).

The EMBI Global, however, is less demanding with respect to liquidity, not requiring a bid-ask spread on transactions or specifying a minimum number of interdealer broker quotes: "The EMBI Global only requires (...) easily accessible and verifiable daily prices. For this reason, the index includes nearly twice as many issues as are in the $\mathrm{EMBI}^{+}$" (MORGAN, 1999, p. 2). 
Despite the differences, both indexes have similar characteristics regarding risk and return (JP MORGAN, 1999, p. 3). Given that the EMBI Global is broader, we used it as the official country risk measure in this study.

Table 1 - Comparative Performance of Total Historical Return of the EMBI Global and EMBI ${ }^{+}$Indexes

\begin{tabular}{ccc}
\hline Year & EMBI Global & EMBI + \\
\hline 1994 & -18.35 & -18.93 \\
1995 & 26.38 & 27.78 \\
1996 & 35.23 & 39.30 \\
1997 & 11.95 & 13.02 \\
1998 & -11.54 & -14.35 \\
1999 & 8.17 & 8.28 \\
Accrued return & 49.47 & 50.06 \\
Average annual return & 7.46 & 7.54 \\
Volatility & 21.44 & 22.49 \\
\hline
\end{tabular}

Source: Morgan (1999).

Modern portfolio theory, which presents risk as an inherent factor in investment decisions, started with the mean-variance model of Markowitz in the 1950s. According to Markowitz (1952), an investor can obtain better returns with the same level of risk by building diversified portfolios composed of shares whose correlations are negative, i.e., portfolios containing assets whose price fluctuations are contrary, as a way to reduce volatility.

The basic assumption is that the return of a portfolio composed of two assets is given by the average of their respective returns, weighted by their relative presence in the portfolio. In turn, risk is given not only by the individual risks, but also by the degree of relation between these assets, measured by the covariance. However, there are risks that cannot be reduced by diversification: systemic risks, i.e., those that affect all assets in a market, which must be taken into consideration when pricing them. According to him, "we should diversify across industries because firms in different industries, especially industries with different economic characteristics, have lower covariances than firms within an industry," such as fluctuations in the money supply, interest rates, fiscal policy and growth rate of the economy (MARKOWITZ, 1952, p. 89).

In this respect, Erb, Harvey \& Viskanta $(1995,1996)$ demonstrated that the country risk is an important predictive variable to calculate the average return on assets in a market, especially in the case of emerging countries, for which reason they developed an asset pricing model that considers this variable. Bekaert \& Harvey (1995) and Harvey (2000) also showed the importance of the volatility of each market to explain the differences in terms of the returns provided by their assets. 
In this context, Martelanc, Pasin \& Cavalcante (2005) and Assaf Neto, Lima \& Araújo (2008) proposed a method to calculate the cost of capital in Brazil that incorporates both the country risk and stock market volatility, to adjust the CAPM to the market conditions of emerging countries. According to the second group of authors, the use of the CAPM as the starting point for the proposed method (of calculating the cost of capital in emerging countries) is suitable because "the model is extremely useful to assess and relate risk and return, despite having limitations, and it is the most widespread among market analysts to estimate the cost of capital" (ASSAF NETO; LIMA; ARAÚJO, 2008, p. 75). Graham \& Harvey (2001) also had made this observation in their previous study.

Finally, Avramov et al. (2012) found evidence of a positive and significant relationship between country risk and the average returns offered by their securities: "countries with higher country risk ratings offer higher returns that cannot be explained by the traditional pricing models" Avramov et al. (2012, p. 149).

Here we intend to analyze the impact of including the country risk variable in the fourfactor model of Carhart (1997), given that tests performed by various authors in studies of developed and emerging markets, such as Lakonishok, Shleifer \& Vishny (1994), Mackinlay (1995), Fama \& French (1996), Carhart (1997), Daniel \& Titman (1997), Dall'Agnol (2001), Grinblatt \& Titman (2005), Bornholt (2007), Fama \& French (2011), Faria et al. (2011) and Machado \& Medeiros (2011), among others, have demonstrated that this model is more suitable to explain the return on assets than the CAPM and other factor models as well.

\section{IDENTIFICATION OF THE EXISTENCE OF VALUE PREMIUM IN THE BRAZILIAN MARKET}

In the first part of this study, consisting of calculating the value premium and comparing this phenomenon between Brazil and the United States, we used the same method adopted by Carhart (1997) to form the portfolios and calculate the risk factors, with some adaptations to adjust it to the specific features of the Brazilian market, as presented next.

\subsection{THE PROCESS OF FORMING THE RISK FACTORS}

The risk factors used in the four-factor model of Carhart (1997) were constructed by using 12 portfolios weighted by size, book-to-market value ratio (BV/MV) and the momentum factor, as suggested by Fama \& French (1993) and Carhart (1997). Initially we considered all the shares listed on the São Paulo Stock Exchange (BMF\&Bovespa), between July 31, 1994 and March 31, 2012. We used this time period because of the greater macroeconomic stability of Brazil after the "Real Plan" stabilization program in July 1994. 
We excluded financial institutions from the sample, as in the method proposed by Fama \& French (1993) and followed by Carhart (1997), as well as stocks that did not present: 1) consecutive monthly quotations for a period of 12 months after the formation of the portfolios; 2) market value on December 31st and June 30th of all the years analyzed; and 3) positive net worth on December 31st of all the years analyzed.

All the returns were calculated monthly and in continuous form, using the natural logarithm of the ratio between the price of the share in month $t$ and the price in month $t-1$, adjusted for payouts, including dividends. For firms with more than one share class, all were included in composing the sample.

We used the CDI (inter-bank deposit rate) as a proxy for the risk-free rate of return, and the Ibovespa as the proxy for the market portfolio.

We constructed 12 portfolios to estimate the factors small minus big (SMB), high minus low (HML) and momentum, as suggested by Fama \& French (1993) and Carhart (1997). For this purpose we relied on the results at the end of June, based on the following steps:

1) the stocks were ordered by market value in June of year $t$ and divided at the median into two groups;

2) within each of these two groups, the stocks were ordered by their BV/MV ratio, calculated in December of year $\mathrm{t}-1$, and then subdivided into three other groups, at the 30th and 70th percentiles;

3) within each of these six groups, the stocks were divided at the median into two groups, according to the worst and best historical returns accrued in the 11 months prior to the date of forming the portfolio.

By this method we obtained 12 portfolios, composed based on size, BV/MV ratio and momentum, with each one containing approximately $n$ assets (number of shares listed on the exchange for the period/12).

The SMB factor was calculated based on the average of the monthly return of the three portfolios of shares of small firms minus the average of the monthly return of the three portfolios of shares of big firms. Likewise, the HML factor was calculated based on the average of the monthly return of the two portfolios with the highest BV/MV ratios minus the average monthly return of the two portfolios with the lowest BV/MV ratios. 
The market risk factor $\left(\mathrm{R}_{\mathrm{Mt}}-\mathrm{R}_{\mathrm{Ft}}\right)$ was calculated based on the monthly historical series between 06/94 and 03/12, by means of the difference between the premium paid by the market (Ibovespa) and the return of a risk-free investment (CDI).

The momentum factor was calculated based on the difference between the average return accumulated in the 11-month period of the three portfolios composed of shares with the highest returns (winners) and the average return accumulated in the 11 months of the three portfolios composed of shares with the lowest returns (losers). We disregarded the returns in the last month to avoid the phenomenon known as bid-ask bounce, as suggested by Carhart (1997).

For the four risk factors (size, BV/MV ratio, market risk and momentum), we obtained the coefficients by means of regression analysis of the historical series of risk premiums of the portfolios against the historical series of the risk factors.

\subsection{EVALUATION OF THE VALUE PREMIUM AND PROCEDURES TO ESTIMATE THE MODELS}

The evaluation of the value premium in the Brazilian market involved comparison of the averages of the returns obtained by value portfolios and growth portfolios, as done by Fama \& French (1993) and Carhart (1997). Besides this, we evaluated its robustness by means of the stability test of the parameters of Chow. For that purpose, we divided the sample into three groups, based on the graphs resulting from the recursive betas, calculated monthly for each portfolio and each model, to assess the behavior of these data during the entire study period.

Next we evaluated the influence of the country risk variable on the conditional returns of assets in the Brazilian market. For that, we considered the EMBI Global as the fifth factor in the pricing model and examined, by means of statistical tests, whether this inclusion increased the model's explanatory power.

To analyze whether the country risk explains part of the variations of the stock returns, we used multiple regressions, where the dependent variable was the monthly returns of the 12 portfolios minus the risk-free rate of return (risk premiums), and the independent variables were the three factors of Fama \& French (1993), the momentum factor of Carhart (1997) and the first difference of the monthly country risk values, so as to assure stationarity of the series, according to equation (4):

$$
\mathbf{R}_{\mathrm{ci}, \mathrm{t}}-\mathbf{R}_{\mathrm{lrt}}=\mathrm{a}+\mathbf{b}\left(\mathrm{RM}-\mathbf{R}_{\mathrm{lr}}\right)_{\mathrm{t}}+\mathbf{s}(\mathrm{SMB})_{\mathrm{t}}+\mathbf{h}(\mathrm{HML})_{\mathrm{t}}+\mathrm{m}(\mathrm{WML})_{\mathrm{t}}+\mathbf{r}\left(\mathrm{dEMBI}^{\mathrm{G}}\right)_{\mathrm{t}}+\mathrm{e}_{\mathrm{t}}
$$


where,

$\mathbf{R}_{\mathbf{c i}, \mathrm{t}}=$ return of portfolio i in month $\mathrm{t}$;

$\mathbf{R}_{\text {Irt }}=$ return of the risk-free asset in month $\mathrm{t}$;

$\mathbf{R}_{\mathbf{M}}=$ return of the market portfolio in month $\mathrm{t}$;

$\mathbf{S M B}_{\mathbf{t}}=$ small minus big, or premium for the size factor, in month $\mathrm{t}$;

$\mathbf{H M L}_{\mathbf{t}}=$ high minus low, or premium for the BV/MV factor, in month $\mathrm{t}$;

WML $_{\mathbf{t}}=$ momentum (winners minus losers) or momentum effect in month $\mathrm{t}$

$\mathbf{d E M B I G}_{\mathbf{t}}=$ first difference of the country risk measure in month $\mathrm{t}$;

$\mathbf{e}_{\mathbf{t}}=$ residual of the model (white noise with normal distribution, zero mean and constant variance).

We checked the significance of including the country risk factor in the four-factor model of Carhart (1997) by comparing the results of the resulting five-factor model against those without inclusion of the country risk, by the Wald F-test. We also performed a comparative analysis of the five-factor model with the three-factor model of Fama \& French (1993) and the one-factor model (CAPM).

Since there were gains by including the fifth factor, it can be stated that country risk is an important macroeconomic variable to explain the conditional returns of assets in the Brazilian market.

\section{PRESENTATION AND ANALYSIS OF THE RESULTS}

\subsection{ANALYSIS OF THE PORTFOLIOS}

Since the data on the EMBI Global index, necessary to compose the our proposed fivefactor model, are only available for Brazil starting in January 1998, the period analyzed differed from that for which we collected the data, going from January 1998 to March 2012.

Table 2 - Average Monthly Return and Average Standard Deviation of the Portfolios

\begin{tabular}{lcccccccccccc}
\hline Portfolios & SLL & SML & SHL & SLW & SMW & SHW & BLL & BML & BHL & BLW & BMW & BHW \\
\hline $\begin{array}{l}\text { Average } \\
\text { return }\end{array}$ & $1.20 \%$ & $1.83 \%$ & $3.08 \%$ & $1.79 \%$ & $2.41 \%$ & $3.16 \%$ & $1.22 \%$ & $0.70 \%$ & $1.58 \%$ & $0.88 \%$ & $1.28 \%$ & $0.85 \%$ \\
$\begin{array}{l}\text { Standard } \\
\text { deviation }\end{array}$ & $9.60 \%$ & $9.36 \%$ & $13.05 \%$ & $9.11 \%$ & $8.23 \%$ & $10.00 \%$ & $8.62 \%$ & $8.86 \%$ & $11.41 \%$ & $9.42 \%$ & $10.59 \%$ & $10.28 \%$ \\
\hline
\end{tabular}

Source: Results of the study

Notes: This table presents the average return and standard deviation of the portfolios, calculated for the period between January 1998 and March 2012. The values are the averages of the 172 months studied. 
As shown in Table 2, the values found for Brazil agree with the evidence found by Fama \& French $(1992,1993)$ that portfolios of the stocks of small firms obtain a higher average return than those made up of the stocks of big firms, over the long run.

Analysis of the value and growth portfolios regardless of firm size shows that the average monthly returns of the value portfolios was higher than that of the growth portfolios, confirming the existence of value premium in Brazil. This corroborates the evidence reported by Fama \& French (1995) and Putranto (2009) that data mining cannot be considered a possible explanation for the existence of the phenomenon, given that once again it has been detected in markets other than the American one.

These results allow another conclusion as well: as found by Fama \& French (2006), the value premium of value portfolios is higher than that detected for growth portfolios. However, as they pointed out, we stress that the results could have been different if the indicator used to measure the value/growth ratio had not been BV/MV (and instead had been, for example, the E/P ratio or dividends).

Applying the same comparison for winning and losing portfolios, the former also presented higher average monthly return than the latter in the Brazilian case. This means that the Brazilian market is characterized by short-term persistence (one year after the formation of the portfolios) in the period analyzed. In other words, the momentum factor helped explain the average stock returns. This evidence agrees with that found by Lakonishok, Shleifer \& Vishny (1994), Carhart (2002) and Phalippou (2004, 2008) for the American market, but contrasts with the findings of Dall'agnol (2001) in a similar study of the Brazilian market.

Finally, analysis of the winning and losing portfolios after their division between value and growth portfolios indicated that, as found by Fama \& French (1995), Brazilian growth portfolios had greater persistence than value portfolios in the period studied.

To check the existence of a difference between the value premiums of small and big portfolios, we compared the average monthly return of the small portfolios characterized by the value premium (SHL and SHW) with the average monthly return of the big portfolios characterized by the value premium (BHL and BHW). Unlike the finding of Fama \& French (2006) that there was no difference between the value premium for small and big portfolios, we found a larger value premium for portfolios of small firms.

With respect to the average monthly standard deviations of the portfolios' returns, these were very close between the small and big portfolios. Therefore, size cannot be considered a 
risk dimension assumed by investors in the Brazilian market, a finding that is contrary to that of Fama \& French $(1992,1993)$ for the American market. For emerging markets, Fama \& French (1998) found annual deviations greater than 50\%, reaching $17 \%$ in the case of Argentina. Here this figure was $210 \%$, corroborating the findings of those authors, suggesting high market volatility. In comparison, the average annual deviation in the United States found by Fama \& French (1998) was $15 \%$.

On the other hand, when comparing the average monthly standard deviations of the value and growth portfolios, we found different values in the Brazilian case: $11.19 \%$ for value portfolios and $9.19 \%$ for growth portfolios. Because of this difference between the variances of value and growth portfolios, the BV/MV ratio can be considered a risk dimension assumed by investors in the Brazilian market, similar to the evidence found by Fama \& French (1992, 1993) for the American market and opposite to that found by Lakonishok, Shleifer \& Vishny (1994) for the same market. Besides this, given the higher variance of the value portfolios, the value strategy can be considered riskier than the growth strategy, as also found by Kouwenberg \& Salomons (2005) for the emerging countries studied by them.

Table 3 - Average Monthly Value Premiums, Average Monthly Standard Deviations and Minimum and Maximum Risk Factor Values, Calculated Based on the Total Sample

\begin{tabular}{lcccc}
\hline Risk factors & Mean & $\begin{array}{c}\text { Standard } \\
\text { Deviation }\end{array}$ & Minimum & Maximum \\
SMB & $0.0107^{* *}$ & 0.0581 & -0.2662 & 0.2466 \\
HML & 0.0015 & 0.0767 & -0.185 & 0.3256 \\
WML & -0.0022 & 0.0582 & -0.272 & 0.1579 \\
Market Return & $0.0156^{* *}$ & 0.0828 & -0.2829 & 0.5631 \\
EMBIG BR & 0.0594 & 0.0433 & 0.0155 & 0.2164 \\
\hline
\end{tabular}

Statistically significant at: *1\%;**5\%; *** $10 \%$.

Source: Results of the study

Notes: This table presents the monthly premium of the following factors: market risk, size, BV/MV, momentum and country risk. The monthly premium is the result of the average of the 172 months studied (January 1998 to March 2012).

The amplitudes of the standard deviations of the risk factors (market, size, BV/MV, momentum and country risk) were similar to those found by Fama \& French (1993) for the American market.

Finally, analysis of the market risk coefficients shows that the average beta values of the value and growth portfolios are virtually the same $(0.32$ for growth portfolios and 0.34 for value portfolios). Therefore, as argued by Fama \& French (2006) for the American market, the CAPM was not able to capture the value premium phenomenon in the Brazilian market. This result can be seen in the table below. 
Table 4 - Average Beta Values of the Value and Growth Portfolios, by Portfolio and by Model

\section{Growth Portfolios}

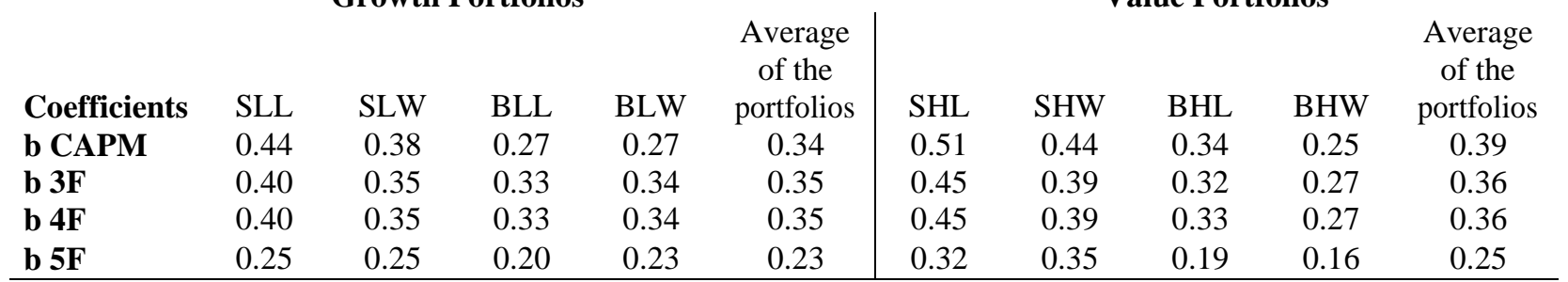

Source: Results of the study

Notes: Average market risk coefficients by portfolio and by model. The portfolios are presented in two groups: growth portfolios on the left, characterized by low BV/MV ratio; and value portfolios on the right, characterized by high $\mathrm{BV} / \mathrm{MV}$ ratio.

\section{COMPARATIVE ANALYSIS OF USE OF THE MODELS (CAPM, THREE- FACTOR, FOUR-FACTOR AND FIVE-FACTOR) TO CALCULATE THE VALUE PREMIUM}

The most striking result of the individualized analysis of the CAPM, three-factor, fourfactor and five-factor models regarding use to calculate the conditional returns of assets in Brazil was that the intercepts for the CAPM were statistically equal to zero for 11 of the 12 portfolios studied, making it impossible to reject the hypothesis that this model helps explain expected returns. Furthermore, the beta coefficient was positive and significant for all the portfolios, making it impossible to reject the basic principle of this model, of a positive relation between portfolio returns and market beta, as can be seen in Table 5 .

Table 5 - Results of the Regression of the CAPM

\begin{tabular}{ccccccccccccc}
\hline Coefficients & SLL & SML & SHL & SLW & SMW & SHW & BLL & BML & BHL & BLW & BMW & BHW \\
\hline A & 0.00 & 0.01 & 0.02 & 0.00 & 0.01 & $0.02^{* *}$ & 0.00 & -0.01 & 0.00 & 0.00 & 0.00 & 0.00 \\
B & $0.44^{*}$ & $0.40^{*}$ & $0.49^{*}$ & $0.39 *$ & $0.34^{*}$ & $0.44^{*}$ & $0.28^{*}$ & $0.36^{*}$ & $0.34^{*}$ & $0.28^{*}$ & $0.36^{*}$ & $0.26^{*}$ \\
\hline
\end{tabular}

Statistically significant at: * 1\%;**5\%;***10\%.

Source: Results of the study

Note: Results for the 12 portfolios formed according to the method of Fama \& French (1993) and used by Cahart (1997). The portfolios are presented in the following order, from left to right: from smaller, with lower BV/MV ratio and loser (SLL), to bigger, with higher BV/MV ratio and winner (BHW). The market portfolio is represented by the Ibovespa. The proxy for risk-free rate of return is the CDI rate. The study period was January 1998 to March 2012.

With respect to the models with three, four and five factors, besides the fact that the results of the intercepts and betas were identical to those found for the CAPM, the performance of the SMB factor was superior to that presented by the HML factor, as demonstrated in Tables 6 and 7 below. This was also reported by Fama \& French (1993) for the American market. 
Table 6 - Results of the Regression of the Three-Factor Model

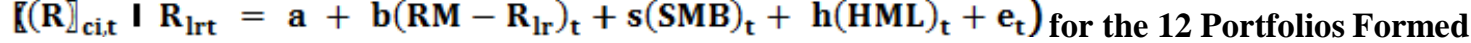

$$
\begin{aligned}
& \text { According to the Method of Fama \& French (1993) }
\end{aligned}
$$

\begin{tabular}{ccccccccccccc}
\hline Coefficients & SLL & SML & SHL & SLW & SMW & SHW & BLL & BML & BHL & BLW & BMW & BHW \\
\hline a & 0.00 & 0.00 & 0.01 & 0.00 & 0.01 & 0.01 & 0.00 & 0.00 & 0.01 & 0.00 & 0.01 & 0.00 \\
b & $0.40^{*}$ & $0.36^{*}$ & $0.43^{*}$ & $0.37^{*}$ & $0.32^{*}$ & $0.39^{*}$ & $0.33^{*}$ & $0.40^{*}$ & $0.33^{*}$ & $0.35^{*}$ & $0.42^{*}$ & $0.28^{*}$ \\
$\mathrm{~s}$ & $0.35^{*}$ & $0.35^{*}$ & $0.48^{*}$ & $0.29^{*}$ & $0.18^{* * *}$ & $0.36^{*}$ & $-0.50^{*}$ & $-0.48^{*}$ & -0.19 & $-0.66^{*}$ & $-0.65^{*}$ & $-0.60^{*}$ \\
$\mathrm{~h}$ & 0.10 & $0.18^{* *}$ & $0.36^{*}$ & -0.03 & 0.05 & $0.19^{* *}$ & $-0.16^{* *}$ & 0.11 & $0.76^{*}$ & $-0.32^{*}$ & -0.04 & $0.61^{*}$ \\
\hline
\end{tabular}

Statistically significant at: * $1 \% ; * * 5 \% ; * * * 10 \%$.

Source: Results of the study

Note: The portfolios are presented in the following order from left to right: from smaller, with lower BV/MV ratio and loser (SLL), to bigger, with higher BV/MV ratio and winner (BHW). The market portfolio is represented by the Ibovespa. The proxy for risk-free rate of return was the CDI rate. The SMB factor was calculated based on the average monthly return of the three portfolios of the stocks of small firms minus the average monthly return of the three portfolios of the stocks of big firms. The HML factor was calculated based on the average monthly return of the two portfolios of stocks of firms with high BV/MV minus the average monthly return of the two portfolios of stocks of firms with low BV/MV. The study period was January 1998 to March 2012.

Table 7 - Result of the Regression of the Four-Factor Model for the 12 Portfolios Formed According to the Method of Fama \& French (1993)

\begin{tabular}{lcccccccccccc}
\hline Coefficients & SLL & SML & SHL & SLW & SMW & SHW & BLL & BML & BHL & BLW & BMW & BHW \\
\hline $\mathrm{a}$ & 0.00 & 0.00 & 0.01 & 0.00 & 0.01 & $0.01^{* *}$ & 0.00 & 0.00 & 0.01 & 0.00 & 0.01 & 0.00 \\
$\mathrm{~b}$ & $0.40^{*}$ & $0.36^{*}$ & $0.43^{*}$ & $0.36^{*}$ & $0.31^{*}$ & $0.39^{*}$ & $0.33^{*}$ & $0.40^{*}$ & $0.33^{*}$ & $0.35^{*}$ & $0.41^{*}$ & $0.28^{*}$ \\
$\mathrm{~s}$ & $0.36^{*}$ & $0.38^{*}$ & $0.46^{*}$ & $0.34^{*}$ & $0.24^{* *}$ & $0.37^{*}$ & $-0.54^{*}$ & $-0.52^{*}$ & $-0.27^{* *}$ & $-0.56^{*}$ & $-0.55^{*}$ & $-0.50^{*}$ \\
$\mathrm{~h}$ & 0.11 & $0.21^{* *}$ & $0.35^{*}$ & 0.02 & 0.11 & $0.20^{* *}$ & $-0.20^{*}$ & 0.08 & $0.68^{*}$ & $-0.22^{*}$ & 0.06 & $0.71^{*}$ \\
$\mathrm{~m}$ & 0.06 & 0.16 & -0.09 & $0.30^{*}$ & $0.33^{*}$ & 0.03 & $-0.23^{* *}$ & $-0.22^{* *}$ & $-0.49^{*}$ & $0.62^{*}$ & $0.62^{*}$ & $0.60^{*}$ \\
\hline
\end{tabular}

Statistically significant at: * $1 \% ; * * 5 \%$; *** $10 \%$.

Source: Results of the study

Note: The portfolios are presented in the following order from left to right: from smaller, with lower BV/MV ratio and loser (SLL), to bigger, with higher BV/MV ratio and winner (BHW). The market portfolio is represented by the Ibovespa. The proxy for risk-free rate of return is the CDI rate. The SMB factor was calculated based on the average monthly return of the three portfolios of the stocks of small firms minus the average monthly return of the three portfolios of the stocks of big firms. The HML factor was calculated based on the average monthly return of the two portfolios of stocks of firms with high BV/MV minus the average monthly return of the two portfolios of stocks of firms with low BV/MV. The WML factor was calculated based on the difference between the average return accumulated in the period of 11 months of the three portfolios composed of winning stocks (higher returns) and the average accumulated in the period of 11 months of the three portfolios composed of losing stocks (lower returns). We disregarded the return of the last month to avoid the bid-ask bounce phenomenon, as suggested by Carhart (1997). The study period was January 1998 to March 2012.

Finally, with respect to the five-factor model, the $\mathrm{EMBI}^{\mathrm{G}}$ coefficient was significant, as presented in Table 8 below. 
Table 8 - Results of the Regression of the Five-Factor Model $\left.R_{\downarrow}(c i, t) \quad R_{\downarrow} I r t=a+b \llbracket\left(R M-R_{\downarrow} I r\right) \rrbracket_{\downarrow} t+s \llbracket(S M B) \rrbracket_{\downarrow} t+h \llbracket(H M L) \rrbracket_{\downarrow} t+m \llbracket(W M L) \rrbracket_{\downarrow} t+r \llbracket\left(\llbracket d E M B I \rrbracket{ }^{t} G\right) \rrbracket_{\downarrow} t+e_{\downarrow} t\right)$ for the 12 Portfolios Formed According to the Method of Fama \& French (1993)

\begin{tabular}{lcccccccccccccccccccc}
\hline Coefficients & SLL & SML & SHL & SLW & SMW & SHW & BLL & BML & BHL & BLW & BMW & BHW \\
\hline $\mathrm{a}$ & 0.00 & 0.00 & 0.01 & 0.00 & 0.01 & 0.01 & 0.00 & 0.00 & 0.01 & 0.00 & 0.01 & 0.00 \\
$\mathrm{~b}$ & $0.25^{*}$ & $0.27^{*}$ & $0.31^{*}$ & $0.25^{*}$ & $0.18^{*}$ & $0.35^{*}$ & $0.20^{*}$ & $0.32^{*}$ & $0.19^{* *}$ & $0.23^{*}$ & $0.31^{*}$ & $0.16^{* *}$ \\
$\mathrm{~s}$ & $0.36^{*}$ & $0.38^{*}$ & $0.46^{*}$ & $0.34^{*}$ & $0.24^{*}$ & $0.37^{*}$ & $-0.53^{*}$ & $-0.52^{*}$ & $-0.27^{*}$ & $-0.55^{*}$ & $-0.54^{*}$ & $-0.50^{*}$ \\
$\mathrm{~h}$ & 0.05 & $0.18^{* *}$ & $0.30^{*}$ & -0.02 & 0.06 & 0.18 & $-0.25^{*}$ & 0.05 & $0.63^{*}$ & $-0.26^{*}$ & 0.02 & $0.66^{*}$ \\
$\mathrm{~m}$ & 0.07 & 0.17 & -0.08 & $0.31^{*}$ & $0.35^{*}$ & 0.04 & $0.22^{*}$ & $0.21^{*}$ & $-0.48^{*}$ & $0.63^{*}$ & $0.63^{*}$ & $0.61^{*}$ \\
$\mathrm{r}$ & $-3.44^{*}$ & $-2.16^{*}$ & $2.81^{*}$ & $-2.57^{*}$ & $-3.16^{*}$ & -1.06 & $-3.07^{*}$ & $-1.71^{*}$ & $-3.30^{*}$ & $-2.64^{*}$ & $-2.33^{*}$ & $-2.72^{*}$ \\
\hline
\end{tabular}

Statistically significant at: * $1 \% ; * * 5 \% ; * * * 10 \%$.

Source: Results of the study

Note: As portfolios are presented in the following order from left to right: from smaller, with lower BV/MV ratio and loser (SLL), to bigger, with higher BV/MV ratio and winner (BHW). The market portfolio is represented by the Ibovespa. The proxy for risk-free rate of return was the CDI rate. The SMB factor was calculated based on the average monthly return of the three portfolios of the stocks of small firms minus the average monthly return of the three portfolios of the stocks of big firms. The HML factor was calculated based on the average monthly return of the two portfolios of stocks of firms with high BV/MV minus the average monthly return of the two portfolios of stocks of firms with low BV/MV. The WML factor was calculated based on the difference between the average return accumulated in the period of 11 months of the three portfolios composed of winning stocks (higher returns) and the average accumulated in the period of 11 months of the three portfolios composed of losing stocks (lower returns). We disregarded the return of the last month to avoid the bid-ask bounce phenomenon, as suggested by Carhart (1997). EMBI ${ }^{\mathrm{G}}$ factor was calculated based on the average values of the first difference of the monthly country risk values, to assure stationarity of the series. The study period was January 1998 to March 2012.

\section{RESULTS OF THE WALD TEST APPLIED TO COMPARE THE MODELS}

The comparative analysis of the models, performed by the Wald test, revealed that the country risk factor contributed to explain the returns of the portfolios, evidence that the fivefactor model is superior to its four-factor peer to explain conditional returns in the Brazilian market, as presented below.

Table 9 - Results of the Wald Test, by Portfolio

\begin{tabular}{lcccccccccccc}
\hline Model/Portfolio & SLL & SML & SHL & SLW & SMW & SHW & BLL & BML & BHL & BLW & BMW & BHW \\
\hline 5F X CAPM (1) & $10.74^{*}$ & $6.98^{*}$ & $6.90^{*}$ & $8.30^{*}$ & $13.08^{*}$ & $3.77^{*}$ & $16.70^{*}$ & $9.53^{*}$ & $33.40^{*}$ & $35.43^{*}$ & $18.01^{*}$ & $48.73^{*}$ \\
5F X 3F (2) & $15.48^{*}$ & $6.69^{*}$ & $4.87^{*}$ & $12.65^{*}$ & $23.87^{*}$ & 1.13 & $17.66^{*}$ & $6.25^{*}$ & $22.35^{*}$ & $34.72^{*}$ & $19.96^{*}$ & $33.19^{*}$ \\
5F X 4F (3) & $30.65^{*}$ & $11.26^{*}$ & $9.39^{*}$ & $17.30^{*}$ & $34.95^{*}$ & 2.20 & $29.86^{*}$ & $8.12^{*}$ & $25.66^{*}$ & $24.54^{*}$ & $11.82^{*}$ & $25.45^{*}$ \\
4F X CAPM (4) & $3.48^{*}$ & $5.23^{*}$ & $5.78^{*}$ & $4.83^{*}$ & $4.81^{*}$ & $4.26^{*}$ & $10.49^{*}$ & $9.59^{*}$ & $31.33^{*}$ & $34.21^{*}$ & $18.84^{*}$ & $49.24^{*}$ \\
4F X 3F (5) & 0.26 & 2.00 & 0.33 & $7.29^{* *}$ & $10.61^{*}$ & 0.07 & $4.65^{*}$ & $4.21^{* *}$ & $16.58^{*}$ & $39.33^{*}$ & $26.37^{*}$ & $35.66^{*}$ \\
3F X CAPM (6) & $5.11^{* *}$ & $6.81^{*}$ & $8.54^{*}$ & $3.47^{*}$ & 1.81 & $6.39^{*}$ & $13.13^{*}$ & $12.05^{*}$ & $35.40^{*}$ & $25.74^{*}$ & $13.09^{*}$ & $46.39^{*}$ \\
\hline
\end{tabular}

Statistically significant at: *1\%;**5\%;*** $10 \%$.

Source: Results of the study

Note: Results of tests comparing the five-factor model $(5 \mathrm{~F})$ with the CAPM, three-factor model (3F) and fourfactor model $(4 \mathrm{~F})$; the $4 \mathrm{~F}$ with the $3 \mathrm{~F}$ and CAPM; and the $3 \mathrm{~F}$ with the CAPM, by portfolio. The portfolios are presented in the following order from left to right: from smaller, with lower BV/MV ratio and loser (SLL), to bigger, with higher BV/MV ratio and winner (BHW). 
By comparing the F-statistics in Table 9, it can be seen that the five-factor model was superior to the CAPM to explain conditional returns in the Brazilian market in $100 \%$ of the cases analyzed. The same comparison between the five-factor and three-factor shows that the null hypothesis of $m=0$ and $r=0$ was rejected for 11 of the 12 portfolios. The same happened in the comparison between the five-factor and four-factor models. It can thus be concluded that the five-factor model presented gains in terms of explaining conditional returns over the three- and four-factor models in $92 \%$ of the cases. This means that inclusion of the country risk factor contributed to explain the conditional returns in Brazil.

Next we considered groups of portfolios (small and big; high and low; winner and loser). From Table 10 it can be seen that for the six small portfolios as a group, the models with five, four and three factors were all better than the CAPM. On the other hand, only the five-factor model was more suitable than the three-factor one. In turn, the five-factor model outperformed the four-factor model. The results were similar for the six big portfolios.

Analysis of the high portfolios as a group, regardless of the small or big classification, shows that the models with five, four and three factors performed better than the CAPM in the Brazilian market. Furthermore, both the five- and four-factor models were better than the three-factor model, and the five-factor model outperformed its four-factor peer. The same pattern repeated for the four low portfolios.

Finally, we analyzed the six winner portfolios, irrespective of designation as small or big, high or low. In this case, the models with five, four and three factors performed better than the CAPM. Besides this, both the five- and four-factor models outperformed the threefactor model. And as before, the five-factor model was superior to the four-factor one. The results for the six loser portfolios were similar.

Table 10 - Results of the Wald Test by Group of Portfolios

\begin{tabular}{lllllll}
\hline Model/Portfolio & SMALL & BIG & HIGH & LOW & WINNER & LOSER \\
\hline 5F X CAPM (1) & $11.54 *$ & $24.74^{*}$ & $55.82^{*}$ & $22.79 *$ & $35.99 *$ & $22.26^{*}$ \\
5F X 3F (2) & $15.43^{*}$ & $15.43^{*}$ & $19.02^{*}$ & $19.02^{*}$ & $40.89^{*}$ & $21.51^{*}$ \\
5F X 4F (3) & $27.04 *$ & $27.04^{*}$ & $31.91^{*}$ & $31.91^{*}$ & $26.97 *$ & $26.97 *$ \\
4F X CAPM (4) & $5.51^{*}$ & $20.72^{*}$ & $53.77^{*}$ & $16.64 *$ & $33.72^{*}$ & $17.90^{*}$ \\
4F X 3F (5) & 3.30 & 3.30 & $5.17 *$ & $5.17 *$ & $47.39 *$ & $13.88^{*}$ \\
3F X CAPM (6) & $6.52 *$ & $29.03^{*}$ & $76.18^{*}$ & $21.84 *$ & $21.04 *$ & $18.48^{*}$ \\
\hline
\end{tabular}

Statistically significant at: * $1 \%$;** 5\%;*** $10 \%$.

Source: Results of the study

Note: The test was run to compare the five-factor model $(5 \mathrm{~F})$ with the CAPM, three-factor (3F) and four-factor models (4F); the 4F with the 3F and CAPM; and the 3F with the CAPM, by group of portfolios. 
Therefore, just as in the case of the individual analysis of each of the 12 portfolios, when the portfolios were analyzed in groups, the conclusion was the same: the country risk factor contributed with extra information to explain the returns of the portfolios analyzed in $92 \%$ of the cases, for which reason we can conclude that the five-factor model is better than the four-factor model of Carhart (1997) in the Brazilian market.

\section{CONCLUSION}

The purpose of this study was to investigate the possible existence of a relation between the value premium and country risk in the Brazilian market between 1994 and 2012, to understand whether this macroeconomic variable is a dimension of risk for predicting conditional returns not captured by value premium.

To do this, we tested some hypotheses, the first regarding the existence of value premium in Brazil. The analysis of this hypothesis allowed concluding that value portfolios tend to perform better than growth portfolios, with an annual difference in return of $13.03 \%$. This provides evidence of the existence of value premium in the Brazilian market.

Given that for Fama \& French (1998), spreads of 4\% per year or lower signal weak evidence for the value premium, the value premium paid in the Brazilian market can be considered significant. On the other hand, just as found by those authors for the American market, no matter how impressive the value premium may appear in economic terms, consideration must go to the annual standard deviations associated with it, which were greater than $100 \%$. Further in relation to the study from 1998, Fama and French found a higher value premium for emerging countries than for the United States (9.47\% a year). The results of our study corroborate this finding.

The second hypothesis involves the behavior of the value premium of Brazilian stocks. Analysis of this hypothesis led to the conclusion that the factors market risk, size, BV/MV ratio and momentum have different influences on the conditional returns of these stocks in comparison with the American market. Therefore, we did not find a common pattern between these two markets, but rather a specific situation for each one.

With respect to the market risk factor, the evidence supports the basic principle of the CAPM, of a positive relation between portfolios' average returns and the market betas, since all the beta values were positive and significant. For this reason, we believe the market risk premium cannot be disregarded in specifying models to value assets in the Brazilian market, a result contrary to that found by Fama \& French (1993). 
On the matter of the size factor, the small portfolios showed better returns than the big portfolios, a result that corroborates that of Fama \& French (1993) for the American market. On the other hand, analysis of the average variances of the monthly returns of these two types of portfolios indicates that the size factor cannot be considered a dimension of investor risk, since the variances of the small and big portfolios were very close, a result contrary to the argument of Fama \& French (1993).

Regarding the BV/MV factor, the value portfolios had higher average monthly returns than the growth portfolios. The difference in the variances of these two portfolio groups allows us to conclude that this factor can be considered a dimension of the risk faced by investors in Brazil. Therefore, the value premium can be considered a compensation for the risk assumed by the investor (individual or institutional), derived from the higher probability of default, lower past profitability, high operational leverage or greater relative risk to future cash flows that characterize value companies. As Fama \& French (2007b: 53) stated, "average convergence in $\mathrm{P} / \mathrm{B}$ is to a large extent the result of rational pricing that aligns expected returns and risks."

Finally, regarding the momentum factor, the results reveal that the Brazilian market is marked by persistence. This evidence agrees with that found by Fama \& French (1996, 2004), according to whom it is preferable to invest in winning portfolios over the long run. Also with respect to persistence, as indicated by Fama \& French (1995), the growth portfolios were more persistent than the value portfolios. On the other hand, contrary to what Fama \& French (1995) found for the American market, in the present study reversal was more common in big portfolios.

The third hypothesis involves the possibility of adding country risk as a variable to predict stock returns, to improve asset pricing models, since it is a risk dimension for conditional returns not captured by the value premium. The analysis of this hypotheses allowed concluding that the inclusion of this fifth factor in the model of Carhart (1997) improved the explanatory power for the Brazilian market, contributing to explain the average return of $92 \%$ of the portfolios analyzed.

Besides this, we found evidence that larger models (in particular including this fifth factor) are more adequate than models with fewer factors regardless of the nature of the portfolio (big or small; value or growth; winner or loser). However, as also noted by Fama \& French (2011), although (unrestricted models) better explain the phenomenon, this explanation is far from complete, since the models were not able to explain all the anomalies 
tested. The fact that the average adjusted $\mathrm{R}^{2}$ was not high corroborates this statement, since it means the five-factor model did not capture the largest part of the variation of average returns in the Brazilian market. Hence, it is necessary to keep searching for macroeconomic, institutional or behavioral variables that can help explain the conditional returns of assets.

After all, we can say that important questions involving the conditional returns of assets are still open to debate. While on one hand our results support the importance of the value premium as a risk factor in this context, on the other we found evidence suggesting the existence of other relevant factors to explain the differences found among emerging markets, as yet not identified. We hope the results found here will lay the groundwork for future studies on the theme. Moreover, our results lead to more questions than answers, indicating there is a long road ahead to identify more variables that can explain asset returns.

\section{REFERENCES}

ALAMBERT, M. O efeito valor, o efeito tamanho e o modelo multifatorial: evidências do caso brasileiro. ENCONTRO DA ASSOCIAÇÃO NACIONAL DE PÓS-GRADUAÇÃO EM ADMINISTRAÇÃO (ENANPAD), 24., 2000, Rio de Janeiro (RJ). Anais... Rio de Janeiro: ANPAD, 2000.

ANEEL. Agência Nacional de Energia Elétrica. Nota Técnica nº . 188/2006-SER/ANEEL, de 23 ago. 2010. Disponível em: 〈www.aneel.gov.br>.

. Nota Técnica nº. 262/2010-SER/ANEEL, de 23 ago. 2010. Disponível em:

<www.aneel.gov.br $\geq$.

ASSAF NETO, A.; LIMA, F.G.; ARAÚJO, A.M.P. Uma proposta metodológica para o cálculo do custo de capital no Brasil. Revista de Administração, v.43, n.1. p. 72-83, jan/mar. 2008.

AVRAMOV, D. et al. The world price of credit risk. Review of Asset Pricing Studies, v.2, n'2, p. 112-152, 2012.

BAILEY, W.; CHUNG, Y.P. Exchange Rate Fluctuations, Political Risk and Stock Returns: some evidence from na emerging market. Journal of Financial and Quantitative Analysis, v.30, n. 4, p. 541-561, 1995.

BARROS, P. S.; PICANÇO, M.B.; COSTA JR., N.C.A. Retornos e Riscos das value e growth stocks no mercado brasileiro. Business Association for Latin American Studies (BALAS), 1998.

BARROS, L.C.; FAMÁ, R.; SILVEIRA, H.P. Aspectos da teoria de portfólio em mercados emergentes: uma análise de aproximações para a taxa livre de risco no Brasil. In:

SEMINÁRIOS DE ADMINISTRAÇÃ̃O (SEMEAD), 2006, São Paulo (SP). Anais... São

Paulo: FEA-USP, 2006. 
BEKAERT, G.; HARVEY, C.R. Time-varying global market integration. Journal of Finance, v. 50, p.403-444, 1995.

BHATIA, A. Sovereign credit ratings methodology. IMF Working Paper, $\mathrm{n}^{\circ}$ 2/170, 2002. Disponível em: <http://www.imf.org/external/pubs/ft/wp/2002/wp02170.pdf>.

BLACK, F. Noise. The Journal of Finance, v.41, n. 3, p. 529-543, 1986.

BLAZENKO, G.; FU, Y. Financial distress and the value premium. Maio 2011. Disponível em: <http://ssrn.com/abstract=1694216>.

BORNHOLT, G.N. Extending the capital asset pricing model: the reward beta approach. Journal of Accounting and Finance, v. 47, n. 1, p.69-83, 2007.

BODIE, Z.; KANE, A.; MARCUS, A. J. Fundamentos de investimentos. Porto Alegre: Bookman, 2000.

BRAGA, C.; LEAL, R. Ações de valor e de crescimento nos anos 90. In: BONOMO, M. A. (Org.). Finanças aplicadas no Brasil. Rio de Janeiro: Editora FGV, 2002.

CAMPBELL, J. Y.; VUOLTEENAHO, T. Bad beta, good beta. American Economic Review, v. 94, n. 5, dec. 2004.

CANTOR, R; PARKER, F. Sovereign credit ratings. Federal Reserve Bank of New York Current Issues in Economics and Finance, v.1, n.3, p.1-6, 1995. Disponível em: <http://www.newyorkfed.org/rmaghome/curr_iss/1995.htm>.

Determinants and impact of sovereign credit ratings. Federal Reserve Bank of New York Economic Policy Review, v.2, n.2, p.37-54, 1996. Disponível em: <http://www.newyorkfed.org/rmaghome/econ_pol/1996.htm>.

CANUTO, O.; SANTOS, P.F.P. Risco soberano e prêmios de risco em economias emergentes. Temas de Economia Internacional 1 da Secretaria de Assuntos Internacionais do Ministério da Fazenda. Brasília, 2003.

CARDOSO, N.; CABRAL, R. The Fama e French Model adapted for developing countries (FFMADC). In: ENCONTRO DA SOCIEDADE BRASILEIRA DE FINANÇAS, 8., 2008, Rio de Janeiro (RJ) Anais... Rio de Janeiro: Ibmec, 2008.

CARHART, M. M. On Persistence in mutual fund performance. Journal of Finance, v.52, p.57-82, 1997.

CARHART, M. M. et al. Testing the conditional CAPM. Working paper, Graduate School of Business, University of Chicago, Chicago, 1996.

CARLSON, M.; FISHER, A.; GIAMMARINO,R. Corporate investment and asset price dynamics: implications for the cross-section of returns. The Journal of Finance, v.59, p. 2577-2603, 2004.

CHAN, L.K.C; LAKONISHOK, J. Value and growth investign: review and update. Financial Analysts Journal, p. 71-86, Jan./Feb., 2004. 
CHATFIELD, C. Model uncertainty, data mining and statistical inference. Journal of the Royal Statistical Society, v. 158, n³, p.419-466, 1995.

CLAESSENS, S; EMBRECHTS, G. Basel II, Sovereign Ratings and Transfer Risk: External versus Internal Ratings. In: BASEL: AN ECONOMIC ASSESSMENT, 2., 2002, Basiléia. Anais... Basiléia: BIS, 2002. p. 1-27. Disponível em: <http://www.bis.org卫.

CHEN, N.; ZHANG, F. Risk and return of value stocks. The Journal of Business, v. 71, $\mathrm{n}^{\mathbf{o}} 4$, p. 501-535, 1998.

COCHRANE, J.H. Presidential addres: discount rates. The Journal of Finance, v.66, nº 4 , p. 1047-1108, 2011.

CONTANI, E.A.R. Um estudo do value premium para ações brasileiras. 2009. 133f.

Dissertação (Mestrado em Administração) - USP, São Paulo, 2009.

DALL'AGNOL, I. Retornos anormais e estratégias reversas. 2001. 73f. Dissertação (Mestrado em Economia) - FGV/EPGE, Rio de Janeiro, 2001.

DAMODARAN, A. Finanças corporativas: teoria e prática. 2. ed. Porto Alegre: Bookman, 2004. 796 p.

DANIEL, K.; TITMAN, S. Evidence on the characteristics of cross sectional variation in stock returns. The Journal of Finance, v.59, n. 1, p. 1-33, 1997.

ELESWAPARU, V.R.; THOMPSON, R. Testing for negative expected market return premia. Journal of Banking and Finance, n. 31, p. 1755-1770, 2007.

ELTON, E. J. et al. Moderna teoria de carteiras e análise de investimentos. São Paulo: Atlas, 2004.

ERB, C.B.; HARVEY, C.R.; VISKANTA, T. E. Country risk and global equity selection.: country credit ratings have substantial predictive power. The Journal of Portfolio Management, v.20, p. 74-83, Winter, 1995.

Expected returns and volatility in 135 countries: projected returns and variances in countries with and without equity markets. The Journal of Portfolio Management, v.21, p. 46-58, Spring, 1996.

FAMA, E. F. Efficient capital markets: a review of theory and empirical work. The Journal of Finance, v. 25, n. 2, p. 383-417, maio 1970.

Market efficiency, long-term returns, and behavioral finance. Journal of Financial Economics, v. 49, p. 283-306, 1998.

Multifactor portfolio efficiency and multifactor asset pricing. Manuscript, Graduate School of Business, University of Chicago, 1995.

Common risk factors in the returns on stocks and bonds. Journal of Financial Economics, v. 33, p. 3-56, 1993. 
FAMA, E. F. Size and book-to-market factors in earnings and returns. Journal of Finance, v. 50, p. 131-155, 1995. 55-84, 1996.

Multifactor explanations of asset pricing anomalies. Journal of Finance, v. 51, p. 1999, 1998.

Value versus growth: the international evidence. Journal of Finance, v. 53, p. 19752006.

. The value premium and the capm. The Journal of Finance, v. 61, p. 2163-2184,

The anatomy of value and growth stock returns. Financial Analysts Journal, v. 63, p. 44-54, 2007.

Disagreement, tastes and assets prices. Journal of Financial Economics, ${ }^{\mathbf{o}} 83, \mathrm{p}$. 667-689, 2007.

Size, value and momentum in international stock returns. Journal of Financial Economics, nº 105, p. 457-472, 2012.

FAMA, E.F.; FRENCH, K. R. The cross-section of expected stock returns. Journal of Finance, v. 47, p.427-465, 1992.

FAMA, E.F.; MACBETH, J.D. Risk, return and equilibrium: empirical tests. Journal of Political Economy, p.607-636, 2001.

FARIA, L.E.C.T. et al. Análise da utilização de um modelo de quatro fatores como ferramenta auxiliar para gestão de carteiras baseadas no IBrX. Brazilian Business Review, v.8, n. 4, p.70-93, 2011.

FEIJÓO, L.G.; JORGENSEN, R.D. Can operating leverage be the cause of the value premium. Financial Management, p. 1127-1153, 2010.

FITCH RATINGS. Sovereign rating methodology. Nova York: Fitch Ratings, 1998. 16p. (Criteria Report). Disponível em: <http://www.fitchratings.com/>.

FLISTER, F.V. Testes do Modelo CAPM Condicional no Mercado Acionário Brasileiro: um estudo dos efeitos momento, tamanho e book to Market no período 1995-2008. 2009. 132f. Dissertação (Mestrado em Administração - Finanças), UFMG, Belo Horizonte, 2009.

GEWEHR, D. H. Avaliação relativa de ações baseada em múltiplos de Mercado projetados e passados: um estudo comparativo de performance na Bovespa. 2007. 108f. Dissertação (Mestrado em Administração - Finanças), UFRGS, Porto Alegre, 2007.

GRAHAM, J.R.; HARVEY, C.R. The theory and practice of corporate finance: evidence from the Field. Journal of Financial Economics, v.60, p.187-243, 2001.

HARVEY, C.R. Predictable risk and returns in emerging markets. Review of Financial Studies, v. 8, p. 773-816, 1995. 
HARVEY, C. R. Drivers of expected returns in international markets. Emerging Markets Quarterly, v. 4, p. 32-49, 2000.

HAUGEN, R. The new finance: the case against efficient markets. New Jersey, Prentice Hall, 1995.

HENS, T. et al. An evolutionary explanation of the value premium puzzle. Journal of Evolutionary Economics, n. 21, p. 803-815, 2011.

HEIJ, C. et al. Econometric methods with applications in business and economics. Oxford: Oxford University Press, 2004.

HUANG, ST. Value premium and macroeconomic conditions: evidence from the Taiwan stock market. Journal of Finance and Economics, v.76, p. 75-83, 2011.

KIM, D. Value premium across countries. Konkuk University, Seoul, 2011. Disponível em: <http://ssrn.com/abstract=2005674>.

KOUWENBERG, R.; SALOMONS, R. The value premium in emerging equity markets and local macroeconomic conditions. Financial markets and institutions, 2005.

LAKONISHOK, J.; SHLEIFER, A., VISHNY, R. W. Contrarian investment, extrapolation and risk. The Journal of Finance, v. 49, p. 1541-1578, 1994.

LETTAU, M.; WACHTER, J.A. The term structures of equity and interest rates. Journal of Financial Economics, n. 101, p. 91-113, 2011.

LING, C.F.; KOO, S.G.M. On the value premium, part I: the existence. Journal of Mathematical Finance, $n^{\circ}$ 1, p. 109-119, 2011. ;.. On the value premium, part II: the explanations. Journal of Mathematical Finance, n. 2, p. 66-74, 2012.

LORENZO, G.; YAN, HONG. Financial distress and the cross-section equity returns. The Journal of Finance, v.65, n.3, 789-822, 2011.

MACHADO, M.A.V.; MEDEIROS, O.R. Modelos de precificação de ativos e o efeito liquidez: evidências empíricas no mercado acionário brasileiro. Revista Brasileira de Finanças, v.9, n. 3, p. 383-411, 2011.

MACKINLAY, A.C. Multifactor models do not explain deviations from the CAPM. Journal of Financial Economics, v.38, p.3-28, 1995.

MALAGA, F.K.; SECURATO, J.R. Aplicação do modelo de Fama e French no mercado acionário brasileiro: um estudo empírico do período de 1995-2003. In: ENCONTRO DA ASSOCIAÇÃO NACIONAL DE PÓS-GRADUAÇÃO EM ADMINISTRAÇÃO (ENANPAD), 28., 2004, Rio de Janeiro (RJ). Anais... Rio de Janeiro: ANPAD, 2004.

MANTOVANINI, R.E.M. A relação risco-retorno: análise do desempenho de modelos de risco e de um modelo comportamental no mercado brasileiro. 2003. 156f. Tese (Doutorado) FGV/EAESP, São Paulo, 2003. 
MARKOWITZ, H.M. Portfolio Selection. Journal of Finance, v. 7, n. 1, p. 77-91, 1952.

MARTELANC, R.; PASIN, R.; CAVALCANTE, F. Avaliação de empresas: um guia para fusões \& aquisições e gestão de valor. São Paulo: Pearson Prentice Hall, 2005.

MESCOLIN, A.; BRAGA, C.M.; COSTA JR.; N.C.A. Risco e retorno das value e growth stocks no mercado de capitais brasileiro. In: ENCONTRO NACIONAIONAL DE ENGENHARIA DE PRODUÇÃO (ENEGEP), 1997, São Carlos (SP). Anais... São Carlos: UFSCar, 1997.

MOODY'S INVESTORS SERVICE. The function of ratings in capital markets. Nova York: Moody's Investors Services, 1997. 7p. (Special Comment). Disponível em: $<$ http://www.moodys.com/ 2 .

Introdução aos ratings da Moody's. Nova York: Moody's Investors Services, 1999a. 19p (Comentário Especial).

Revisão da política de teto soberano. Nova York: Moody's Investors Services, 2001. 4p. (Metodologia de Rating). Disponível em: <http://www.moodys.com.br>.

MORGAN, J.P. Introducing the emerging markets bond index plus (EMB+). Nova York: J.P. Morgan Securities Inc, Emerging Markets Research, jul. 1995. 8p. (Market Brief).

Introducing the J.P. Morgan emerging markets bond index global (EMBI Global). Nova York: J.P. Morgan Securities Inc, Emerging Markets Research, aug. 1999. 8p. (Market Brief).

MUSSA, S.; SANTOS, J.O.; FAMÁ, R.A. A adição do fator de risco momento ao modelo de precificação de ativos dos três fatores de Fama \& French, aplicado ao mercado acionário brasileiro. In: CONGRESSO USP DE CONTROLADORIA E CONTABILIDADE, 7., 2007, São Paulo (SP). Anais... São Paulo: USP, 2007.

NUNES, M. S. A relação entre o mercado de ações brasileiro e as variáveis macroeconômicas no período pós-plano real. 2003. 133f. Dissertação (Mestrado em Economia) - Universidade Federal de Santa Catarina (UFSC), Florianópolis (SC), 2003.

NUNES, M. S.; COSTA JR, N.C.A.; MEURER, R. A relação entre o mercado de ações brasileiro e as variáveis macroeconômicas: uma análise econométrica para o Brasil. Revista Brasielira de Economia, n. 59, v.4, p. 585-607, 2005.

PHALIPPOU, L. What drives the Value premium. INSEAD, 2004. 2008. Where is the Value premium. Financial Analytics Journal, v. 64, n. 2, p. 41-48,

PUTRANTO, D.A. The evidence of the value premium, the size effect, and momentum versus contrarian strategies in indonesian stock market. 2009. 92f. Dissertação (Mestrado em Ciências Econômicas e Finanças) - Maastricht University, Indonésia, 2009.

ROLL, R. A critique of the asset pricing theory's test. Journal of Financial Economics, n. 4, p. 129-176, 1977. 
ROSS, S.A. The current status of the capital asset pricing model (CAPM). The Journal of Finance, v.33, n. 3, p. 885-901, 1978.

ROSTAGNO, L.; SOARES, R.O.; SOARES, K.T.C. Estratégias de valor e de crescimento em ações na Bovespa: uma análise de sete indicadores relacionados ao risco. Revista Eletrônica de Administração, Porto Alegre (UFRGS), n. 48, 2005.

SECURATO, J.R.; ROGERS, P. Estudo comparativo no mercado brasileiro do Capital Asset Pricing Model (CAPM), Modelo 3-Fatores de Fama e French e Reward Beta Approach.

RAC-Eletrônica, Curitiba, v.3, n. 1, art.9, p.159-179, Jan/Abr.2009.

SILVA, E. L.; MENEZES, E. M. Metodologia da pesquisa e elaboração de dissertação. 2000. Programa de pós-graduação em Engenharia de Produção, Universidade Federal de Santa Catarina, Florianópolis, 2000.

VAIHEKOSKI, M. Portfolio construction for tests of asset pricing models. Financial Markets, Institution \& Instruments, v.13, n. 1, p. 1-39.

VERONESI, P.; SANTOS, T. Habit formation,the cross section of stock returns and the cashflow risk puzzle. Journal of Financial Economics, n. 98, p. 385-413, 2010.

WANG, H.; YU, J. An empirical assessment of Models of the Value premium. University of Minnesota, September, 2011.

ZHANG, L. The Value premium. The Journal of Finance, v.60, n. 1, p. 67-103, 2005. 